\title{
The Two Levels in Natural Law Thinking
}

\section{Karl Olivecrona}

translated with an introduction by Thomas Mautner

Note: this document closely resembles the published version in Jurisprudence 1 (2010) pp. 197-224.

\section{Introduction: A Lawless Natural Law?}

Natural Law (Ius Naturae) can be understood as a system of norms and principles suitable for guiding the conduct of free agents. In Latin, such a system was called ius. ${ }^{1}$ In this sense we have, for example, ius naturae, ius canonicum, and the title doctor utriusque iuris. A particular norm or a set of norms, especially if created by an act of legislation, was called lex, a law. Although lex could also be used in the sense of a system of law, Suárez, who discussed these words and concepts with admirable clarity, preferred to reserve lex for precepts from a superior which command or forbid and have obligatory force. $^{2}$ What the heading asks is whether there could be a Natural Law (a system of norms and principles guiding human conduct) without leges, that is, without commands or prohibitions with obligatory force, and in that sense 'lawless'.

Still, the heading has a paradoxical air, and to prevent confusion it is probably best to leave behind the eye-catching formulation and instead think in terms of two radically distinct conceptions, or two levels, within the kind of natural law theory which was proposed in the major works of Grotius and Pufendorf.

That there is such an important dualism in that kind of theory is the main thesis in the text to which the following notes are an introduction. The text is a translation of 'Die zwei Schichten im naturrechtlichen Denken' by Karl Olivecrona. Its main point is that in their doctrine of Natural Law the two authors had little to say about the law of nature in the sense of a set of divine imperatives. They did not refer to that law when explaining what it is that belongs to a person in the state of nature, nor did they do so when explaining the nature of injury, of property, of contracts, or when discussing the consequences of transgressions - and their views on these matters made up the core of their Natural Law doctrine. His account, which explains this, is entirely different from what is on offer in the literature, and this is one reason why it should be of special interest.

\footnotetext{
1 In another sense, ius means a power or a right, something that a person has. But this does not pertain to the distinction here made between Law (ius) and a law (lex).

2 Francisco Suárez (1547-1616) De legibus ac deo legislatore, 1613 (1.8.3; 1.16.1; 1.17.3).
} 


\section{The Author and his Intellectual Environment}

Karl Olivecrona, the author of the essay now presented in translation, read law in Uppsala and occupied the chair of procedural law in Lund from 1933 to $1964 .{ }^{3}$ His main work in legal philosophy is Law as Fact. ${ }^{4}$ The bibliography below lists other writings of his in English that deal with topics germane to the present essay. The aim of these notes on the author and his intellectual background is to put his essay in context. They may also serve to correct some mistakes in the secondary literature.

In the background is the strong influence of the naturalistic and anti-metaphysical philosophy of Axel Hägerström (1868-1939), professor of practical philosophy in Uppsala from 1911 to 1933. During a talk in Uppsala in 1909 he said:5

Naturalism, in the sense that there can be no separate reality which is not a part of the natural order, is the only scientific 6 outlook ...

He took the natural order to be the all-encompassing empirical space-time reality. As a consequence, moral and legal concepts which on analysis were shown to require supranaturalist or nonnaturalist assumptions would be unacceptable.

3 The name is pronounced with the main stress on the second vowel, pronounced 'ee' in English. Another eminent author on law of the same name was Knut Olivecrona (1817-1905), grandfather of our author. He was a professor of law in Uppsala, married to the feminist author and journalist Rosalie Roos (182398), member of the Riksdag, politically conservative, and a member of the High Court of Sweden. He became internationally known for his opposition to the death penalty in De la peine de mort (Paris 1868) and other writings.

${ }^{4}$ K. Olivecrona, Law as Fact (Stevens \& Sons, 2nd edn 1971). In a typescript dated 1976 he indicated that the title ought rather to have been The Structure of a Legal Order, and added: 'For the 1971 edition the title Law as Fact was retained because it gives the most succinct expression to my intentions. But it is not altogether convenient to use the same title [as was used in 1939] for a completely new book.'

5 (1980) Filosofisk tidskrift 1, no 2.

6 'Scientific' is to be taken in the wide sense of vetenskaplig (like German wissenschaftlich), ie that the view or method is theoretically respectable and meets criteria of rationality. 
But Hägerström also rejected attempts to provide a naturalistic reduction of moral and legal concepts. ${ }^{7}$ His inaugural lecture ${ }^{8}$ in 1911 presented a radical new theory. Its main thesis was that moral ideas are neither true nor false. There can be no such thing as a 'normative reality'. This was the first time a meta-ethical non-cognitivism had been formulated and argued for. Next followed remarkably original and probing analyses ${ }^{9}$ of the concepts of law, duty and rightness, published in 1916 and 1917. These writings have received limited attention due to extraneous circumstances (language, prose style, timing, academic fashion).

One problem with Hägerström's account was that although its basic drift was noncognitivist, parts of the discussions of the concepts of duty and rightness seemed to point in an error-theoretical direction. The overall account would then be inconsistent. ${ }^{10}$

Philosophical naturalism of the kind favoured by Hägerström-and many others - has a strong intuitive appeal. It fits a certain view of the philosopher's task: to promote enlightenment and beat down obscurantism in its various forms, including religious superstition, clericalism and reactionary politics, aims to which Hägerström was strongly committed. ${ }^{11}$ 'La vérité est en marche', he said in a lecture in the early 1920s—a clear signal of his commitment. ${ }^{12}$ He combined this stance with an evolutionistic view of the history of thought, inspired by Comte and reinforced by the theories of ancient or primitive thought found in the works of JG Frazer, L Lévy-Bruhl and P Huvelin, to name

7 Some of his arguments are similar to those earlier used by G.E. Moore against the so-called naturalistic fallacy, but an influence is unlikely.

8 'On the truth of moral ideas'. Since that time, 'idea' has fallen out of favour, and preference is given to 'belief', statement' or 'proposition'.

9 Translated in Inquiries into the Nature of Law and Morals (Skrifter utgivna av Kungliga Humanistiska Vetenskapssamfundet i Uppsala/Acta societatis litterarum humaniorum regiae Upsaliensis 40) (Uppsala, 1953) 17-256.

10 Non-cognitivism is the view that all statements in a particular domain are neither true nor false, whilst error theory is the view that they are all false or all imply a falsehood. The paradigmatic error theory is, of course, atheism.

11 John Mackie’s error-theoretical 'Refutation of Morals' (1946) 24 Australasian Journal of Psychology and Philosophy 77 was no doubt similarly inspired.

12 'La vérité est en marche, et rien ne l'arrêtera’ (Zola, 'J’accuse!'). The moral earthquake that was the Dreyfus affair was seen by many people, then and now, as a struggle between good and evil, light and darkness. 
a few. ${ }^{13}$ Alf Ross, strongly influenced by Hägerström in the 1930s and 1940s (as was Karl Olivecrona), fully assented to this statement of Comte's:

Par la nature même de l'esprit humain chaque branche de nos connaissances est nêcessairement assujettie dans sa marche à passer successivement par trois états théoriques différents. L’état théologique ou fictif, l’état métaphysique ou abstrait; enfin, l’état scientifique ou positif. ${ }^{14}$

Hägerström once said that this pattern of three stages certainly fits the development of ideas of law and justice in European history. ${ }^{15}$

His analyses of ancient Roman Law are impressive, indeed astounding, in their breadth and depth. ${ }^{16}$ What he wanted to show was the essential role played by magical and superstitious beliefs. An obligation, for instance, was originally thought of as an actually existing intangible bond. The performance of certain rites and uttering of certain formulas was thought to produce real change. ${ }^{17}$ On the Comtean schema, later developments in Roman Law and the rise of early modern natural law theory would belong to the next 'metaphysical' stage, which would in turn, in our time, be overcome and replaced with a realistic legal theory.

13 More information on this can be found in Carla Faralli, 'Anthropology and History in the Study of Law’ Rechtstheorie. Beiheft 9 (Duncker \& Humblot, 1986) (E. Kamenka, R.S. Summers and W.L. Twining (eds), Soziologische Jurisprudenz und realistische theorien des Rechts) 275-288, and in her Diritto e Magia (Bologna: Clueb 1987).

14 Auguste Comte, Opuscules de philosophie sociale 1819-22 (Paris, 1883) 100, as quoted by Ross in Kritik der sogenannten praktischen Erkenntnis (Critique of so-called practical knowledge) (Meiner, 1933) 249, a work dedicated to Hägerström in which his decisive influence is acknowledged (in the preface dated May 1933).

15 This view is recorded in a note dated 1925, in a set of notes from Hägerström's seminars and conversations with him, probably taken by Olivecrona. A proof dated 1926 of Hägerström’s account of his philosophy has 'the usual path from superstition to metaphysics', with reference to law and morals. This remained his outlook, but the quoted formulation is missing from the re-written passage in Die Philosophie der Gegenwart in Selbstdarstellungen, vol 7, Raymund Schmidt (ed) (Meiner, 1929).

16 Der römische Obligationsbegriff (The Roman Concept of Obligation) I, II (Skrifter utgivna av Kungliga Humanistiska Vetenskapssamfundet i Uppsala/Acta societatis litterarum humaniorum regiae Upsaliensis 23, 35) (Uppsala 1927, 1941).

17 Hume seems to have been the first philosopher to remark on the affinity between legal and superstitious acts: Treatise of Human Nature 3.2.5 §14. 
It was in keeping with this that when Hägerström was given the opportunity to present his philosophy internationally, he chose as a motto Praeterea censeo metaphysicam esse delendam. ${ }^{18}$

This climate of philosophical opinion — not only in Uppsala, but also in Vienna, Paris and many other places where naturalist or positivist anti-metaphysical philosophy was located-influenced the early work of Olivecrona and Ross. But their views changed significantly from the 1940s onward-a fact sometimes overlooked in the secondary literature. One reason for the changes was no doubt a sense of dissatisfaction with the theoretical implications of combative naturalism, which opposes beliefs that are taken to be widely held, false, and harmful, and which therefore will find an error-theory inviting. But on reflection, an error-theory of law and morals can seem quite implausible, and is in any case incompatible with a non-cognitivist approach (emotivist, prescriptivist, expressivist, etc), for which in their view there were convincing reasons. As the two authors gradually distanced themselves from some of their earlier views, they did not, however, move in the same direction. Significant differences emerged. For instance, Olivecrona rejected Ross's view that statements implying that a law is binding can be analysed as predictions of how courts of law and other public authorities will act.

It may be of interest to dwell for a moment on the general change in the philosophical climate that occurred during the time-span we are considering. In the 1920s and 1930s, not only 'metaphysics' but also 'natural law' ${ }^{19}$ would be pronounced with a note of disdain clearly audible in the utterances of naturalist and positivist philosophers. The words would connote superstition, perhaps refined and in disguise, but still nothing but sophistry and illusion. Over the decades, attitudes changed. The chief dragons to be slain after the 1940s were no longer clerical obscurantism and political reaction. The need to écraser l'infâme was becoming less urgent, as much greater evils were seen to arise from ideologies (racism, fascism, nazism, communism) that were used to justify monstrous crimes. 'Metaphysics' lost its abusive overtone, and so did 'natural law'.20

18 Selbstdarstellung (see n 15). The allusion is to the words 'Moreover, I believe that Carthage must be destroyed', by which Cato regularly expressed his hostility towards Carthage.

19 Kelsen also saw a close affinity between 'metaphysics' and 'natural law'. H. Kelsen, General Theory of Law and State (Harvard University Press, 1946) 396 (German original published in 1928).

20 One episode that illustrates the mellowing in the intellectual climate in this respect occurred in the course of a conversation between Olivecrona, Alexander Peczenik and myself (19 November 1979) when natural law came to be mentioned in a mildly disparaging tone of voice. Olivecrona replied that theories like those of Grotius and Pufendorf deserved respect, because their ambition was to provide a rational theory and to overcome a more dubious intellectual heritage. He did not think they had got it right, but their endeavour ought not to be regarded with disdain. 


\section{A Central Concept in Modern Natural Law Theory}

Olivecrona's investigations into seventeenth century Natural Law theory had their origins in his involvement with the posthumous publication of the second volume of Hägerström's Der römische Obligationsbegriff in 1941. The work was incomplete, in that a full account of consensual contracts was missing. But Hägerström had given an outline of it in a major essay in $1934 .{ }^{21}$ In this essay, the Roman concepts were contrasted with those of Modern Natural Law Theory i.e. the theory which is considered to have Grotius and Pufendorf as founders). The essay, edited by Olivecrona, was published as a monograph in 1965, in a German translation. When preparing this edition, he would have begun to look more closely at the theories of Grotius and Pufendorf, and in this way he would have come to the view that a revised and improved account was needed. This happened in the period 1966-75, as indicated in the preface to the second edition of Rättsordningen: ${ }^{22}$

[T] he account of the concept of a right in Natural Law theory has been entirely rewritten on the basis of investigations undertaken the last few years.

One result of these investigations is the essay we have before us. It draws attention to the fact that the concept of a person's 'own' (suum in Latin) is at the very core of Modern Natural Law Theory. ${ }^{23}$ Combined with the idea of the sacrosanct character of the human person (which calls for absolute respect for persons), this concept enters into the explanation of the nature of wrongdoing, the justifiable use of force, and the creation of rights and obligations. Conspicuously absent from this essential part of the theory are

21 'Nehrman-Ehrenstråles uppfattning av grunden för ett löftes juridiskt bindande kraft, belyst genom å ena sidan romersk, å andra sidan naturrättslig rättsåskådning' (Nehrman-Ehrenstråhle’s view of the foundation of the binding force of a promise, illustrated by comparison with the viewpoints in Roman Law and in Natural Law) in Minnesskrift ägnad 1734 års lag vol II (Stockholm, 1934) 571-630. Translated as: Recht, Pflicht und bindende Kraft des Vertrages nach römischer und naturrechtlicher Anschauung (Right, duty and the binding force of contract, according to roman law and natural law theories) (Skrifter utgivna av Kungliga Humanistiska Vetenskapssamfundet i Uppsala/Acta societatis litterarum humaniorum regiae Upsaliensis 44:3) (Stockholm, 1965).

22 Rättsordningen (Liber, 1976 [1966]). The content of this Swedish work is very similar to that of Olivecrona's Law as Fact.

23 Olivecrona called it 'classical', but most scholars use that word for theories that emerged in ancient or mediaeval times, and 'modern' seems preferable since the theory belongs to the modern era. 
appeals to any law understood in terms of commands and prohibitions emanating from a superior.

Olivecrona found it remarkable that this core and its fundamental significance for a proper understanding of the theories of Grotius, Pufendorf and those who followed had, to the best of his knowledge, been entirely overlooked in the literature. ${ }^{24}$

The concept of suum ${ }^{25}$ is indeed an indispensable element in the theory as it is formulated by Grotius. His natural law theory is first and foremost about the legitimate use of force. The fundamental principle underlying the theory is that there is one necessary and sufficient condition for the legitimate use of force. Only an iniuria ${ }^{26}$ (a wrong) can justify the use of force. It was, of course, well recognised that what can be legitimately done may be inadvisable or bad from other points of view: be they pragmatic or moral. ${ }^{27}$ But Modern Natural Law Theory is essentially a theory of justice, and its main principle is indeed that as far as justice is concerned an iniuria is necessary and sufficient for the permissible use of force. And iniuria, in turn, is defined in terms of suum. It consists in a violation, an attack, a trespass on that which pertains to the person. In this sense, the suum is indeed at the core of the theory. The word denotes the realm over which the individual is sovereign. ${ }^{28}$

How is the boundary of the realm defined? Iniuria consists in abstaining from that which is another's. But it seems that that which is another's is only defined as that which it is an

24 This and the previous paragraph draw on 'Hägerström och naturrätten' (Hägerström and Natural Law) in Uppsalaskolan—och efteråt. Rättsfilosofiskt symposium (The Uppsala School—A Symposium on the Philosophy of Law), Uppsala, 23-26 May 1977 (Symposia Universitatis Upsaliensis Annum Qungentesimum Celebrantis 6. Acta Universitatis Upsaliensis) (Uppsala, 1978) 25-31.

25 This is a wide sense of the word (and in context the other pronouns: meum etc). Other authors confined the meaning to property, things owned.

$26 \quad$ Iniuria was the word used by Grotius and Pufendorf. Other writers preferred laesio.

27 Non decet omne quod licet was a commonplace. Cf Digests 50.17.144: Non omne quod licet honestum est.

28 Grotius was not the first to use the word (and in context, the other pronouns: meum etc) in a wide sense. Donellus had done so, according to Peter Stein ('The Origin of the Modern Civil Law' in J.A. Ankum et al (eds), Mélanges Felix Wubbe: offerts par ses collègues (Editions Universitaires, 1993) 43952, 449). Hertius (1652-1710) noted (De Socialitate ... dissertatio, III, 9, in his Commentationum atque opusculorum ... tomi tres (Frankfurt, 1700)) that the word was used in both a narrow and a wide sense, and that the latter could be found in the Digests. Other natural-law authors, including Achenwall (171972), preferred to use the word only for things owned (Prolegomena iuris naturalis (Göttingen, 1781 [1758]) §§123, 124), but Kant, who often lectured on Achenwall's texts, used the word in a wider sense (Metaphysik der Sitten (Metaphysics of Morals), AA p. 238). 
iniuria to take or trespass on. Without a defined bounda ry, the concept lacks content and the basic principle of justice likewise. As noted by Olivecrona, Hägerström saw this as a shortcoming of the theory. It is interesting to note that essentially the same objection was made three centuries earlier by William Ames, who complained about the vacuity of the praecepta iuris. ${ }^{29}$ The precept neminem laedere, for instance, is not valid without qualification, because in certain circumstances it is not wrong to harm a person-an unjust aggressor, say — and the formula is acceptable - but of no use-if taken to mean that unlawful harm is unlawful.

Against this, Olivecrona shows that the concept of the suum, with its links to the concepts of iniuria and alieni abstinentia (leaving alone that which belongs to another), does have a content, which is given not by definition but by enumeration. Grotius and Pufendorf provided what he calls a suum 'catalogue', a list of the items that can properly be said to be a person's own. The principle that the use of force is justified only in response to an attack on that which is a person's own is not vacuous, because the two authors offered a list itemising its content.

The primary items in Grotius's list are one's life, body, limbs, reputation, honour, sexual integrity, and one's actions. Added to this are the things necessary for one's safety. ${ }^{30}$

These are one's own by nature without further ado (Grotius 2.17.2: mera natura; Pufendorf calls them connate). Other items become one's own as a result of transactions which by their nature have that effect (accedente facto humano in Grotius; Pufendorf calls them adventitious): foremost among them are property rights and claims against others. The transactions that result in additions to what is one's own derive their validity from acts of will: promises proffered and accepted. ${ }^{31}$ Since natural freedom and equality are taken as axiomatic, all authority and subjection is created by acts of will. These

29 De conscientia et ejus jure vel casibus libri quinque (Amsterdam, 1630) (posthumously translated as Conscience with the Power and Cases thereof, 1639) 5.1.19-20. William Ames (1576-1633) was for some time a Fellow of Christ's College, Cambridge. In 1611 he moved to the Netherlands. He was active on behalf of the anti-remonstrant party that prevailed at the synod of Dordrecht in 1618. (One consequence of its success was that in 1619 Grotius was condemned to life imprisonment.) From 1622, Ames held a chair at Franeker. When raising doubts about the praecepta iuris, and in general about the place of reason in matters of faith and morals, arguing that revelation was a better guide, Ames may have had Grotius in mind.

30 Grotius 2.17.2.1: Natura homini suum est vita ... corpus, membra, fama, honor, actiones propriae. Grotius 1.2.5.7: Sunt enim quaedam quae vitae aequiparantur, ut existimatio, pudor virginalis, fides matrimonii, aut sine quibus vita tuta esse non potest ...

31 Grotius actually allows for rights and obligations to come into being naturally not only by promises, but also by procreation, and by damage culpably caused. Pufendorf's explanation of filial obligation is different. 
principles of justice are natural and would remain valid even in the absence of divine authority. $^{32}$

In the subsequent literature, these distinctive conceptions of the suum and creative power inherent in the human will to bring obligations and rights into being were rarely discerned with great clarity; rather they tended to be fudged with conceptions of commands and prohibitions emanating from a legislative authority, be it God, or the State, or Reason.

One significant exception was an author now unknown to most: Heinrich Köhler (16851737). ${ }^{33}$ In his Exercitationes, he placed the concepts of suum and iniuria firmly at the centre of his own theory, which, he insisted, was essentially the same as Grotius's. Both for him and for Grotius, ${ }^{34}$ the fundamental principle of natural law is that injustice consists in usurpatio alieni (taking that which belongs to another) and, positively formulated, that justice consists in alieni abstinentia or, in other words, suum cuique tribuere.

His account of items, connate or adventitious, that are one's own differs from Grotius's in that he offers a general statement that might be read as a definition, and he offers a longer list of items that are one's own. He wrote: ${ }^{35}$

The complex of all goods which a person has we can conveniently call his own.

This sounds like a definition. By 'goods' (bonum) he means all that on which one's happiness depends. But Köhler did propose a list of sua connata. ${ }^{36}$ It included the items listed by Grotius and a few more, among them natural equality and the abilities bestowed on us by nature. The list ends with 'bonum jucundum, ${ }^{37}$ \& quae possunt esse alia' (things

32 Grotius Prol. §11. He refers to 'what he has said so far', which inter alia includes alieni abstinentia.

33 Professor in Jena. He invented the word 'Monadologie' for the title of his German translation (1720) of Leibniz's short treatise on the principles of philosophy (1714). Author of Iuris naturalis ... exercitationes VII, Jena(1729) 1738, and Juris socialis et gentium ad ius naturale revocati specimina VII, Jena, 1735

34 Grotius Prol. §44.

35 Exercitationes, §xvi. Complexus omnium bonorum, quibus aliquis instructus est commode vocare possumus suum.

36 Exercitationes, §xxvii.

37 A firmly established tradition recognised three kinds of the good: bonum jucundum pleases, bonum utile is advantageous, beneficial, useful, and bonum morale or honestum is morally good. 
that give us pleasure, and whatever else there may be). This, it must be said, seems rather casual. It is as if Köhler was suggesting that if you can think of some further items that you would like to add to the list, feel free! He might reply that there is a restriction: you must think that your happiness depends on it. Even so, it would have troubling implications, since the list, supposed to indicate the scope and limits of the permissible use of force would become permissive indeed.

\section{More About the Two Levels}

The writers on natural law would want their theory to be coherent. The question was how to combine the conception of a law consisting of commands and prohibitions, backed by divine authority, with the conception of a normative order which contains the elements sketched above. The former tracks all obligations to the superior authority, the latter takes obligations to arise together with rights, when an agreement has resulted in the alienation of a part of one's natural freedom. In the former case, an obligation without a superior legislative authority is inconceivable. In the latter case, this is not so, as Grotius remarked in Prol. $§ 11 .{ }^{38}$

But at this level, obligation is conceived in two different ways. One is narrower: two parties create through their volitions a nexus, such that one party is under an obligation and the other has a right. The relation creditor-debtor is the paradigm. Failing to pay violates the creditor's right, which is part of his suum. So understood, there are no rights and no obligations in the state of natural freedom and equality: they come into being as a result of transactions between free and equal individuals. The wider conception of obligation is that any violation of a person's suum, no matter whether the item violated is a right or something else, is failing to fulfil an obligation. It is in that sense that ownership gives rise to obligations (on others to respect one's property; cf Grotius Prol. §33). This leads to the curious consequence that, supposing that we are subject to a superior being who has authority over us and whose will it is that we fulfil our obligations - for instance, that we pay what we owe-it would follow that we would have an obligation to fulfil an obligation.

There is, then, a dualism. Obligation and bindingness can have two sources. One source is the will of a being vested with superior authority in relation to those subject to that authority; the other source is the wills of individuals capable of creating obligations and rights. This dualism has persisted in legal theory. A statement from Georges Davy may serve as an interesting illustration: ${ }^{39}$

$38 \quad$ See n 32 above.

39 Georges Davy (1883-1976), 'Pourquoi vaut la foi jurée’ (1917) 24 Revue de metaphysique et de morale 327-53. Davy, incidentally, sees in this will-theory an expression of, and a necessary condition 
(328) L'obligation aujourd'hui nous apparaît ... oeuvre de volonté. (329) La doctrine reconnaît d'ordinaire cinq sources d'obligations: contrats, quasicontrats, délits, quasi-délits, loi. M. Planiol a très bien montré qu'il n’y en a en réalité que deux: l'accord des volontés entre le créancier et le débiteur et la volonté toute-puissante de la Loi qui impose une obligation à une personne malgré elle et dans l'interêt d'une autre.

(330) ... la solidarité des deux notions d'obligation et de volonté. Si, en effet, le quasi-contrat, le délit et le quasi-délit sont exclus, c'est qu'on n'y trouve point en réalité de vraie intention volontaire de produire l'état d'obligation. Quant à la Loi ... elle représente en effet au même titre que lui l'expression d'une volonté. Elle est l'émanation de la volonté collective comme le contrat celle de la volonté individuelle. Volonté ... en définitive la seule puissance capable à nos yeux d'obliger, ... une puissance de conscience.

In the history of political and legal thought many attempts have been made to subsume one under the other—but this is not the place to explore that topic.

\section{How Do We Know What is Ours?}

Our knowledge of the principles of natural law is so certain that nobody can deny them without doing violence to himself. They can be no more denied than the testimony of our external senses. This was Grotius's view (Prol. §39). He also quotes many eminent authors who have expressed similar sentiments, but that only shows widespread consensus, not truth. Can there be any rational foundation for such intuitions? Köhler seemed to suggest that we know empirically what will be conducive to our happiness, and seemed prepared to include all of it in his list. But his inclusion of other items, such as those also listed by Grotius, does not have that kind of empirical basis.

The empirical fact that human beings need society is an inviting solution, but an unsatisfactory one. Peaceful coexistence requires respect for persons and what is theirs. But in order to satisfy that requirement, we must know what it is that is to be respected. So peaceful coexistence presupposes knowledge of what is on the list of what is theirs.

In the conceptual framework of natural law theory of the kind discussed here, the sacrosanctity of the person and of that which is truly a person's own is a basic concept. The appeal to sociality belongs to an entirely different conceptual framework, in which

for, civilised life, nationally and internationally. In contrast, the will as a creator of binding norms is irrelevant in primitive society. The primitive outlook (333) is inferior. 
the use of force is justified not by reference to persons' intrinsic claim to respect, but by reference to their interest in peaceful coexistence and safety.

To be safe, we take precautions as best we can: against the forces of nature and bad things that might happen to us_-not least from bêtes méchantes, be they men or beasts, who through ill grace defend themselves if attacked. In this perspective, concepts like justice, wrongdoing, rights and obligations have no place. If you attempt to harm another being, it cannot, given this conceptual framework, be a reaction to an iniuria, though it can be in response to a threat, and it makes no difference whether the being that tried to endanger your safety is a snake, a dog or a human being. In this framework, the precepts designed to preserve peace and safety do not include the precept to do no wrong, but they do include a precept not to provoke hostile reactions. Whilst in the contrasting naturallaw framework some hostile actions are permissible while others constitute a wrong, this is not so in this alternative framework, where those normative concepts have no place. Instead, it contains only precepts for the guidance of those concerned to preserve peace and safety.

If this is so, the theory of natural justice cannot be fully grounded in a theory of the conditions for peaceful coexistence.

Returning now to the conceptual framework of natural law theories and the question of how we know what is ours: attempts to provide a definition seem unpromising, and the enumeration in the proposed lists needs a criterion. It seems that an answer, as good as any, is one suggested-perhaps unwittingly_by a turn of phrase in van der Muelen. ${ }^{40}$ Commenting on Grotius 1.1.4, he notes that a certain right is as it were in our very bones: ... persona hominis, ut ita dicam, ossibus jus aliquod inhaeret. The Oxford Latin Dictionary explains that in the plural, the word for 'bones' can refer to the innermost part of the body, especially as the seat of the emotions.

What the word suggests is that the real basis is emotional, not rational. The items in the list belong to a great variety of categories-Köhler's is quite revealing-and they do not really have anything in common except that they indicate situations in which we feel justified in hitting back. This is what really determines the content of the list.

The problem is to find the scope and limits for the justified use of force. The answer is given along the following path of reasoning. The use of force is justified if and only if an iniuria has taken place. An iniuria is a violation of the suum. Something belongs to the suum if and only if it is included in the suum list. Something is included in the suum list if and only if we feel that violation of it justifies the use of force. Conclusion: the use of force is justified if and only if we feel that the use of force is justified.

40 In his annotations, which make up in verbosity for what they lack in acuteness, to his edition of Grotius’s De iure belli ac pacis, vol 1 (Utrecht, 1696). 
This recourse to feeling rather than reason would be to the great discredit of the theory, in the view of authors such as Bentham. ${ }^{41}$ Those with less confidence about the place of reason in ethics would be less inclined to condemn that approach.

In conclusion: what the following essay demonstrates is, briefly, that modern natural law theories of the kind that began with Grotius and Pufendorf have the suum as a core concept. A violation of it (iniuria), actual or threatened, is the only just cause of war. ${ }^{42}$ The suum is also a key concept in explaining the binding force of contracts, property and much else. The way these theories are discussed in the contemporary secondary literature leaves this pivotal notion out of account. It is like a Hamlet without the Prince of Denmark. The essay that follows should help towards a re-instatement of the notion.

\section{The Text}

The text presented here is a translation of 'Die zwei Schichten im naturrechtlichen Denken’ by Karl Olivecrona (1897-1980), published in (1977) 63 Archiv für Rechts- und Sozialphilosophie 79-103. Most of the original footnotes are included. Some have been cancelled and their content included in the main text. A few footnotes which simply reproduced a passage in Latin have been omitted, where a reference to the original locus seemed sufficient. Insertions by the translator are within brackets.

Grotius and Pufendorf are also discussed in Olivecrona’s Law as Fact (Stevens \& Sons, 2nd edn 1971). Other writings of his in English on related topics are:

'Appropriation in the State of Nature: Locke on the Origin of Property' Journal of the History of Ideas 35 (1974).

‘Locke’s Theory of Appropriation’ Philosophical Quarterly24 (1974).

'The Will of the Sovereign. Some Reflections on Bentham's Concept of “a Law"' American Journal of Jurisprudence 20(1975).

'The Term “Property” in Locke’s Two Treatises of Government' Archiv für Rechts- und Sozialphilosophie 61 (1975).

'Bentham’s “Veil of Mystery”’ in Current Legal Problems (London: Stevens, 1978).

The major works on natural law discussed are:

41 Jeremy Bentham, An Introduction to the Principles of Morals and Legislation, J. Burns and H.L.A. Hart (eds) (London: Athlone, 1970) ch 2, §14.

42 Grotius 2.1.1.4: Causa iusta belli suscipiendi nulla esse alia potest, nisi iniuria. 
- Hugo Grotius (1583-1645), De jure belli ac pacis libri tres (Three books on the law of war and peace), first published in Paris in 1625. Grotius made various corrections and additions in later editions. Olivecrona used an edition with annotations by Gronovius, Amsterdam 1711. The standard edition is now that of B.J.A. De Kantervan Hettinga Tromp (1939), revised by R. Feenstra, S.E. Persenaire et al (Scientia, 1993). The most recent translation into English is by F. Kelsey et al. 1925 (and later reprints).

- Samuel Pufendorf (1632-1694), De jure naturae et gentium libri octo (Eight books on the law of nature and nations), first published in Lund in 1672. Pufendorf introduced corrections and substantial additions in later editions. Olivecrona used an edition with annotations by Mascovius, Frankfurt and Leipzig 1744. The standard edition is now that of F. Böhling (in Gesammelte Werke (Collected works), vol 4, Akademie Verlag, 1998). The most recent translation into English is by C.H. and W.A. Oldfather, 1934 (and later reprints).

Both works were translated into French by Jean Barbeyrac (1674-1744), ${ }^{43}$ who also supplied copious annotations: Grotius, Le droit de la guerre et de la paix (Amsterdam, 1724), and Pufendorf, Le droit de la nature et des gens (Amsterdam, 1706). Olivecrona used the second edition (with corrections and additions) (Amsterdam, 1712). Barbeyrac made further additions and corrections in a later edition (Amsterdam, 1734).

In what follows, references to passages in these and certain other works are editionneutral, by Book, Chapter, Section, and for Grotius sometimes also Sub-section. ${ }^{44}$

$43 \quad$ He fled Catholic persecution in France, and was a professor in Lausanne from 1711 to 1717, when he took up a chair in Groningen. He was a frequent contributor to Bibliothèque Raisonnée, a highbrow monthly journal.

44 The number of different editions and translations of these works is large indeed, and the unhelpful practice of some recent scholars to refer only to page numbers in the particular edition they happen to be using is to be deplored. 


\title{
The two levels in natural law thinking ${ }^{45}$
}

\author{
Karl Olivecrona
}

Seventeenth-century natural law theory, as formulated by Grotius and Pufendorf, assumes that there is a 'law of nature'. It could be expected that the natural law theorists would primarily have been providing interpretations of this law. But when studying their writings, it soon becomes evident that this is hardly the case. To a large extent it seems as if their thought moved, as it were, at a different level, one which does not refer to the law of nature. This will be the subject-matter of the present inquiry.

According to the natural law theorists, every law consists of commands and prohibitions issued by a superior power. This power is either God or a human authority, a potestas civilis (here called 'sovereign'). The law of nature contains commands and prohibitions issued by God. Human law (ius humanum voluntarium or positivum) contains commands and prohibitions issued by the sovereign. ${ }^{46}$

\section{The content of the law of nature}

According to Grotius (Prol. 8) the law of nature contains two main principles. One is expressed by the words alieni abstinentia. Grotius means that all interference with that which belongs to someone else must be avoided (Prol. 44). The other principle states that one is obliged to fulfil one's promises (promissorum implemendorum). Three further rules are supplied: if one is in possession of something that belongs to someone else, one must deliver it to the other party; if one has derived benefit from it, one must offer compensation; and one must also give compensation for any harm to another caused by one’s own fault (damni culpa dati reparatio). Grotius also mentions, as belonging to the law of nature, that human beings are permitted to inflict deserved punishments (poenae inter homines meritum). In this case there is, however, no command or prohibition, but only the observation that there is no prohibition against inflicting punishment, if it is merited.

45 Translation of ‘Die zwei Schichten im naturrechtlichen Denken’ (1977) 63 Archiv für Rechts- und Sozialphilosophie 79.

46 This paper connects with 'Das Meinige nach der Naturrechtslehre' ['My Own’ in Natural Law Theory] (1973) 59 Archiv für Rechts- und Sozialphilosophie 197. The editions used are: Grotius, De iure belli ac pacis (Amsterdam, 1712), with added notes by Gronovius, and Pufendorf, De jure naturae et gentium (Frankfurt and Leipzig, 1744), with added notes by Mascovius. As for the divine nature of Natural Law, see Grotius 1.1.10 and 1.1.15.1; Pufendorf 1.6.4, 1.6.18 and 2.3.20. 
Pufendorf differs from Grotius insofar as he assumes that natural law has as its basis a fundamental command (a fundamentalis lex naturae). He formulates it as follows (2.3.15): 'It is fitting for all human beings that in their mutual relations they should cultivate and preserve peaceful sociality of a kind that is suitable for the character and destiny of mankind. By sociality (socialitas) I understand a disposition towards every other person such that one feels that there are bonds in relation to them of benevolence, peacefulness, love and even through reciprocal obligations.' In a different context Pufendorf states some particular commands of the law of nature (2.2.9). For certain reasons he has arrived at the position that the natural condition of man is not war, but peace: and this condition of peace depends on the laws 'not to harm another (alterum non laedere)—unless it is in response to an attack-, to leave others in peaceful possession of what belongs to them (alieni abstinentia), to keep one's agreements conscientiously, and to promote the welfare of others insofar as this does not lead to a neglect of stricter obligations'.

When the natural law theorists mention the principle not to harm others, it should be observed that they use the word harm (damnum) in a very wide sense. To harm another means to deprive him of something that 'belongs' to him, or to reduce its quantity or quality. Neminem laedere means the same as alieni abstinentia. ${ }^{47}$

The two natural law theorists agree on the main content of the law of nature: There must be no interference in that which belongs to another human being, and promises must be fulfilled. ${ }^{48}$

$47 \quad$ Grotius 2.17.2.1; Pufendorf 3.13: Damnum etsi proprie ad res pertinere videatur, a nobis tamen ita laxe accipietur, it omnem laesionem complectatur. ... Notat omnem laesionem, corruptionem, diminutionem, aut sublationem eius, quod nostram iam est, aut interceptionem eius, quod ex iure perfecto debebamus habere. Cf H. Denzer, Moralphilosophie und Naturrecht bei Samuel Pufendorf (C.H. Beck, 1972) 147: 'The concept damnum matches the extent of the precept ut nemo leadatur [not to harm anyone].'

48 The principle neminem laedere (harm nobody) is one of the [three well-known] iuris praecepta [precepts of justice] of Stoic origin. [The other two are honeste vivere-live honorably-and suum cuique tribuere-let everyone have what is his.] They were included in the Digests. On the relation between stoicism and natural law theory, cf Hägerström, Recht, Pflicht und bindende Kraft des Vertrages nach römischer und naturrechtlicher Anschauung Recht (= Skrifter utgivna av Kungliga Humanistiska Vetenskapssamfundet i Uppsala 44:3) (Stockholm, 1965) 44ff. Curiously, the natural law theorists rarely mention the suum cuique tribuere. This was not because they rejected that principle. On the contrary, they regarded it as self-evident. Pufendorf writes, e.g. ( $P$ 8.1.5) that no king would be so out of his mind as to prohibit his subjects from observing the principle suum cuique tribuere. In another place (1.7.6) he explains why he thinks that the principle need not be discussed. The Roman jurists had defined justice as the constant and enduring will to let everyone have what is his (constans et perpetua voluntas, suum cuique 
The first commandment presupposes, of course, that one can know what it is that belongs to a person. But the law of nature says nothing about that. It would seem, therefore, as if that command would lack content unless it is determined, by agreement or by positive law, what belongs to whom.

This was not the view of the natural law theorists. They had a theory of what belongs to the individual, independently of laws and agreements. They referred to it as 'one's own', suum. ${ }^{49}$ The principle of alieni abstinentia was therefore not vacuous in the state of nature.

The suum

The theory of the natural law theorists concerning the suum was not primarily about private property. Private property was introduced by agreement. But, independently of any agreement, every individual had already, by nature, something that belonged to him.

No conceptual definition was given of the suum. But the natural law theorists gave an account of what it consisted of. They give a catalogue of the elements of the suum. In this way the theory had a definite content.

According to Grotius, one's life, body, limbs, liberty, good reputation, honour and one's actions belong to oneself by nature (1.2.1.5; 2.17.2.1). Pufendorf gives a similar list (3.1.1). He also mentions pudicitia (sexual integrity; cf 2.5.11). Grotius also counts it as part of the suum, although it did not appear in the catalogue (1.2.5.7; 2.1.7).

According to Grotius and Pufendorf it is by nature that every human being has a sphere that belongs to him. The subject of the suum is of course a spiritual self which possesses the body etc. The sphere of the suum is the realm of this spiritual personality.

As Pufendorf notes in various places (eg 4.4.5), animals have no suum. Human beings have such a sphere of their own in virtue of their rationality.

The theory of the original freedom and equality of all human beings is closely connected with the theory of the suum. Freedom means negatively, that the individual is not subject to anyone else. Positively it means that the individual is sovereign within his own sphere; he has a power or a right over himself and his own actions (potestas in se).

\section{Right and wrong}

tribuendi). This defines justice as a virtue of persons, a topic not much discussed by the theorists of Natural Law. Their main subject matter was the lawfulness of actions.

49 [Or, depending on the context, meum, tuum, nostrum, or vestrum.] 
The right way to act, iustum (sometimes also called iustitia) is defined negatively by Grotius. Right is that which is not wrong. ${ }^{50}$ In order to know what is iustum, one has to know what constitutes a wrong (iniuria). This is clearly indicated. A wrong is committed if one takes from another something that belongs to him (alienatio alieni). Pufendorf is of the same opinion (1.7.14f; 3.1.1).

The concepts iustum and iniustum are, that is, defined by means of suum. Every trespass across the boundary of another's suum is a wrong; and a wrong consists in such a transgression.

There is obviously a congruence between the concept of iniuria and the prohibition against doing harm to another. It is precisely those actions which violate a prohibition that constitute an iniuria.

\section{Extension of the suum}

The prohibition, independent of agreements and laws, against doing harm to others, was given a tangible content through the account of the sphere of the suum. The extent of this sphere could, however, be enlarged by means of human acts of will.

The increased extent could, in the state of nature, come about in two ways: by acquisition of property rights and other real rights [i.e. rights in things—res], or by acquisition of rights against other persons by means of promises.$^{51}$ In both cases it had to be explained how the acquisition could come about. The explanation would have to be consistent with the assumption of original freedom and equality of all human beings. ${ }^{52}$

\section{Acquisition of private property}

When God created the world, he gave the earth to mankind. Therefore everything was in the beginning common property. But people were allowed to change the initial order and

\footnotetext{
$50 \quad$ Grotius Prol. §44; 1.1.3.1; Hägerström (n. 48) 50f.

51 In civil society legislation could also increase the extent (Grotius 2.17.2.1). In the following, parental power will not be discussed. On this topic, the two authors disagreed (Grotius 2.5.1; Pufendorf 6.2.4). [Cf Olivecrona (n. 4) 281.]

52 Denzer (n 47) $146 \mathrm{f}$ does not mention the suum but writes of that which is protected by the 'precept of the invulnerability of the other party', and enumerates the items of the suum 'catalogue'. His opinion seems to be that the extent of what is protected is established by interpreting the law of nature. This does not seem correct. For Pufendorf, the suum was a realm objectively given. Its core was founded in nature, and the possible increase of its extent took place through the human will.
} 
to introduce private property. This was done by an agreement that was made even before civil society was set up. ${ }^{53}$

Private property was, then, based not on the law of nature, but on the human will. The object of the property right was included in the owner's suum. Consequently the prohibition against alienatio alieni applied; it was an iniuria (a wrong) to take an object from its owner. ${ }^{54}$

The question next arises of how the inclusion of an object into the personal sphere of an individual was conceived. It would be a mistake to expect an explicit and complete answer to such a question in the writings of the natural law theorists. But certain inferences can be made from their accounts.

\section{Division and occupation}

The original community was to a large extent abolished by division, according to Grotius (2.2.2.5). Every participant thereby made an original acquisition (2.3.1). It is easy to understand how this could come about. A portion was allotted to each. At the same time everyone renounced his share in that which fell on others. In this way, common property changed into private property.

Grotius remarks that it was only on this first occasion that division was a mode of original acquisition. Subsequently there is only one mode of original acquisition, i.e. occupation. ${ }^{55}$ ] This permits an important conclusion. The goods which had not been distributed did not remain in common. When agreeing to distribute goods, mankind had also abolished common property in the remaining goods. That which was not distributed became res nullius. This opened up the possibility of occupation. It could occur if, and only if, the thing was res nullius. ${ }^{56}$

$53 \quad$ Grotius 2.2.2.5; Pufendorf 4.4. Before the introduction of the right of ownership, every individual was according to Grotius allowed to use what his nature required, and to consume in accordance with his natural needs (1.2.1.5 and 2.2.2.1). These were necessary means to an end prescribed by nature (2.5.5). Pufendorf insisted that there had to be an agreement.

$54 \quad$ Grotius 1.1.10.4 and 2.8.1.1; Pufendorf 3.1.1.

$55 \quad$ Grotius 2.3.1 and 2.3.4.1. Extinctive modes of acquisition were not recognised. Not even specification could establish ownership to something that belonged to another person (Grotius 2.3.3).

$56 \quad$ Grotius says (2.3.19.1) that things that are without an owner because of derelictio or for some other reason return to their original condition, and Gronovius comments that such things become res communes. This can hardly be correct. If Grotius held that view, he would have been inconsistent. He does say, unequivocally (2.2.3.3): Quae communia omnium fuerunt, et in prima divisione divisa non sunt, ea non 
An obstacle to acquisition of property by means of occupation was therefore removed, because of the universal renunciation. It is a different question how occupation is carried out, and what its basis is. Grotius rejects the view that occupation was introduced by a common agreement between the nations (ius gentium); he asserts on the contrary that occupation doubtless was a natural mode of acquisition (haud dubie naturalis modus acquirendi, 2.8.1.2; 2.3.4.1).

So it was presupposed that man by nature was capable of making things become his own by means of occupation. This should be seen together with the general proposition that man had a moral capacity lawfully to possess things as his own (qualitas moralis ... ad aliquid iuste habendum ..., 1.1.4). Furthermore, man had also, as is stated loc cit, a moral capacity to perform acts with legal effects (qualitas moralis ad agendum). The power that brought about the effect was the will, though it had to be rational (rationalis, 2.6.1.2). ${ }^{57}$

If a thing was res nullius (and there was no other impediment) occupation could take effect, as a natural mode of acquisition. By nature, prescinding from positive law, it belongs to the finder or occupier (2.8.6). Two elements were required: first, the will of the occupant to have the thing as his own, and, secondly, an external sign of this will (2.3.11). It was the will that brought about the effect; but it had to be made known by some external sign. For land, walking on it was for the most part the sign, and for chattels touching with one's hands (2.8.6). As a result, the thing became included in the suum sphere of the occupant: it was united with his personality.

\section{Transfer of property}

The derivative modes of acquisition depended according to Grotius partly on the law of nature (lex naturae), partly on ius gentium (general agreement) and partly on the law of the state (lex civilis, 2.7.1.1). For present purposes it is only those of the first kind that are of interest.

iam divisione, sed occupatione transeunt in ius proprium, nec dividuntur, nisi postquam propria esse coeperunt. Cf Pufendorf 4.6.2.

57 What Hägerström writes about the qualitas or facultas moralis ad aliquid iuste habendum vel agendum ((n 48) 55) seems unsatisfactory. What Grotius writes at 2.5.10.1 makes it quite clear that by facultas agendi he means the ability to bring about a legal effect. He writes (2.5.10.1, discussing the validity of marriage): Principium et hic et in aliis actibus humanis, unde ius oritur, est ius illud, quod facultatem moralem interpretati sumus, simul cum voluntate sufficiente. [Both here and in other human actions which give rise to a right, is that right which I understand as a moral faculty, together with an sufficient act of will.] Cf 2.5.3.1. [Grotius uses ius, a right, both for the faculty and for the ensuing right, obviously in two different senses.] 
When Grotius in this context speaks of lex naturae, he does not mean divine command and prohibitions. The right to property was not introduced and regulated by any law of nature in that sense. By lex naturae is rather understood 'that which follows from the very nature and power of ownership' (2.7.2.1). The right to transfer was included in the right of ownership (2.6.1.1). Transfer of ownership was therefore a natural mode of acquisition in the same sense as was occupation.

According to Natural Law transfer of ownership did not require formalities or delivery (2.6.1.2). The transfer was produced by the parties' acts of will. The will would, however, have to be expressed by some external sign, since it would not be in accord with human nature to attribute legal effects to a merely internal act of will. . $^{58}$ The will of the transferor was not sufficient. By nature, acceptance by the transferee was necessary for the transfer to be accomplished. ${ }^{59}$

Transfer of property came about, then, as an effect of the joint acts of will of the parties. The object was separated from the sphere of one of the parties, and received into the sphere of the other party.

The manner in which the two volitions took effect was not further explained by Grotius. But Pufendorf is more informative. He gives a fine account of how the transfer of property took place. He writes that the modes of acquisition which depend on the power of the right to property require two volitions: one on the part of the transferor, the other of the transferee. It is a characteristic of a transfer that the thing is transferred in accordance with the owner's will and that the thing is not taken from him by force. But to complete the acquisition the consent of the acquirer is also required. Because it would be absurd to allow that a thing which is physically separate from me would, as it were, be joined to me,. ${ }^{60}$ without my having willingly embraced it and given my consent.

58 Grotius 2.6.1.1. This had general application. Cf 2.4.3: nudis animi actibus efficientiam iuris tribuere non fuerat congruum naturae humanae. Gronovius commented [alluding to Jeremiah 11:20 or Romans 8:27]: Non est enim hominum pectora scrutari. [It is not given to human beings to test the hearts and minds of men.] Pufendorf 4.9.3: It would not accord with human society to attribute to merely internal acts the power to create rights which would be used against others. Cf Hägerström (note 48) 67.

Grotius 2.6.2. Gronovius commented: Aliqua indicio externo quod oculis vel auribus accipiatur.

[The acceptance may be by a visible or audible sign.] It could be given in advance, in which case the will was presumed to perdure, unless a change was announced (censetur durare voluntas, nisi mutatio appareat). Grotius adds that the reason why the law of nature insists on acceptance of a promise is the same as in the case of transfer of ownership.

$60 \quad$ Pufendorf 4.9.2: Ut alienum a priori dominum res accipiat, hunc quoque consentire necesse est; cum inconveniens sit, ut res, substantia sua physica a me separata, mihi velut adiungatur, ni voluntate et consensu meo eandem amplexus fuerim. Cf 4.10.8. 
It is then clear how a transfer comes about. By his will, the owner can separate the thing from his sphere. This is all he can do. He is not able to insert the thing into the suum of the recipient. It is significant that Pufendorf calls the transferor's act an oblatio (from offerre = to hold out (a thing), for someone else to take). ${ }^{61}$ Only a volition on the part of [as you suggest (TM)] the recipient can incorporate the thing in his suum, i.e. his personality. ${ }^{62}$ The volition of the recipient is comparable to that of an occupant. But the announcement of the will can be done in a different way. Pufendorf (4.9.3) mentions nods, gestures, words spoken or written. In this instance, in contrast to occupation, touching the thing is not required.

There was already in the state of nature a right of inheritance as soon as the right of ownership had been introduced. The right of inheritance was not, however, an immediately natural mode of acquisition. It was based on the presumed will of the deceased. One could not consider it his will that after death his property should become res nullius and thus open to occupation. One would have to assume that it was in accordance with his will that his property should go to those related to him (Grotius 2.7.3; Pufendorf 4.11.1). In principle, acceptance was necessary also in this case. According to Pufendorf, positive law accepted by fiction that this condition was satisfied (4.9.2; cf 4.4.10 in fine).

\section{Belonging and ownership}

The theory of acquisition of property was about belonging: how by means of original acquisition a res nullius could become united with the suum of an individual and how, by means of derivative acquisition, a thing could make a transition from the suum of one person to that of another. There was, however, together with this belonging, a further element in the right of ownership. This was a moral capacity (facultas moralis) to demand the delivery of a thing, if it had without the owner's consent ended up with someone else. If the owner made such a claim, the possessor became obliged to hand it

$61 \quad$ Pufendorf 4.4.10: Naturale est, ut in translatione dominiii ab uno in alterum non solum in isto requiratur oblatio, sed et in hoc acceptatio. Translatio is identified with alienatio (4.9.4). Quite consistent with this is his formulation translatio et acquisitio (3.5.4).

62 Cf Pufendorf 4.9.8 on ius ad rem in contrast to ownership: ius autem ad rem praesupponit rem, de qua agitur, nondum plene mecum fuisse coniunctam, et alterum ex peculiari obligatione teneri efficere, ut illa res mecum coniungi possit. igitur ipsius persona est urgenda, ut rem velut vacuam mihi sistat, quo a me possit adprehendi. [A right to a thing presupposes that the thing in question has not yet become fully conjoined with me, and that it brings it about that the other party is bound by a special obligation to see to it that the thing can be conjoined with me. Therefore the other party is to be urged that the thing be made ownerless as it were, so that it can be apprehended by me.] 
over. This facultas moralis originated in the agreement by which the right of ownership was introduced. ${ }^{63}$ It belonged to the person who owned the thing, and does not play a part in the theory of acquisition of property. ${ }^{64}$

\section{Promises}

The binding force of a promise could simply have been grounded on the natural law precept that promises ought to be fulfilled. But this is not what the natural law theorists propose. They argue in an entirely different way, when they try to explain the legal effect of a promise. In so doing, the natural-law precept is not even mentioned.

This is due to the fact that the natural-law precept does not imply any right for the promisee. The great problem for the natural law theorists was: how can one individual acquire a right against another sovereign personality? It was taken for granted that a right is a power that one person has over another. But how could such a power come into being? The answer was that it could only come into being through the activity of the parties themselves.

Natural law theory distinguished between two kinds of promise. One kind is the promise to transfer an object (promissio dandi); the other kind is the promise to do something (promissio faciendi). In both cases promissio was regarded as the transfer of a right. ${ }^{65}$

At first sight this seems peculiar. It is quite foreign to us to think of a promise as a transfer of an already existing right. But in natural law theory this way of thinking is of

$63 \quad$ Grotius (2.10.1.2) and Pufendorf (4.13.3) both maintained that the obligation stems from the initial contract, and that the obligation to return a thing to its rightful owner obtained even if no special claim had been made. If there were no obligation unless a claim was made, the right of ownership would be too weak and uncertain. For instance, the owner might be ignorant of who was in possession of this thing and therefore unable to claim it. So the initial agreement must have been that every possessor immediately had an obligation to return it. As Pufendorf put it: Nimis debilis futura erat vis dominii, et nimis sumtuosa atque anxia custodia, si non nisi tunc res foret reddenda, quando dominus ea repetit; cum illi saepe non possit constare, quonam res sua pervenerat.

64 Children and those of unsound mind did not have a rational will and could not acquire any property rights as far as the Law of Nature is concerned. According to Grotius, ius gentium had determined that for the sake of the common good all mankind be taken to represent children and the mentally unfit. This made acquisition possible (2.3.6): Ius gentium ob utilitatem communem introduxit, ut et infantes et furiosi dominia accipere et retinere possent, personam illorum interim quasi sustinente humano genere. This was further elaborated by Pufendorf (4.4.15).

65 Cf Hägerström (n. 48) 70f; M. Diesselhorst, Die Lehre des Hugo Grotius vom Versprechen (Böhlau, 1959) 35, 51; and F. Wieacker in Festschrift für Hans Welzel (Walter de Gruyter, 1974) 12f. 
fundamental significance. Grotius explicitly treats the promise as an analogue to transfer of property (2.11.1.3). According to Pufendorf it was commonly accepted that a promise was a transfer of a right (3.5.2).

This theory is based on the idea that the individual is incapable of creating a new right. He could only renounce a right which already belonged to him. This was the sense of the proposition in Grotius (2.11.8.1) that a promise derives its power from the right of the promisor (vim accepit ex iure promittenti). ${ }^{66}$

\section{Promissio faciendi}

The analogy between a promissio faciendi and the transfer of the right of property was based on the fact that one's own actions belonged to the suum. As elements in the suum these actions were treated analogously to the objects of the right of ownership. The power over one's own actions (potestas in se) was according to Grotius a right (ius); and this right was similar to the right of property. As mentioned earlier, the right of ownership was taken to include the right to transfer it (Grotius 2.6.1.1: inest hoc in ipsa dominii natura). By analogy it followed that it was possible to transfer the right to a future action of one's own. ${ }^{67}$

In order to show how such a transfer took place, Grotius distinguishes three ways of speaking about one's own intentions. One way is by simply announcing one's present intention (2.11.2). There is nothing wrong with such a statement, provided that it is true. But one is not bound by it: one has the right to change one's mind.

Secondly, one can let it be known that one has made a firm decision to act in a certain way, and that it is necessary to stand by that decision (2.11.3). This is called pollicitatio. The effect is that one becomes bound according to the Law of Nature. But the person to whom the pollicitatio is addressed acquires no right against the promisor. Grotius adds that there are many instances in which a person is bound without there being a right in another party. The duty to show compassion or gratitude is like that, and so is the duty to be constant and faithful.

66 Likewise in Pufendorf: the obligation derives its force from the transfer of the right (3.5.4). Cf 3.7.6: Quaevis promissio vim accepit ex potestate promittentis.

67 After asserting, at the beginning of the chapter on promises, that man can place himself under an obligation by his own will, Grotius continues (2.11.1.3): Adde quod, voluntas sufficienter significata, transferri rei dominium potest, ut ante diximus, quid ni ergo possit transferri et ius in personam, aut ad transferendum dominium (quod ius ipso dominio minus est) aut ad aliquid agendum, quippe cum in actiones nostras par ius habeamus atque in res nostras? 
Thirdly, an announcement can be made in such a way that one displays a will to bestow a right on the person to whom one is speaking. In this instance, there is a complete promise (perfecta promissio, 2.11.4.1).

That which is to be transferred is the power over a future action. The transfer takes place in a manner analogous to the transfer of property. What the promisor is able to do is to exclude the action from his own sphere of suum and let the other party dispose of it. This brings about an alienation of a part of one's own freedom (alienatio particulae libertatis). As with acquisition of property, acceptance is necessary (2.11.14). The promisor cannot incorporate the action with the recipient's suum. The incorporation can only come about by the will of the recipient. With the acceptance the transfer of the right is completed.

It is the will of the two parties that produces the effect. But given the general principle that in human affairs legal effects cannot be ascribed to a purely internal act of will, it is necessary that the will be announced by an external sign (Grotius 2.11.11; cf 2.4.3 and 2.6.1; closely followed in Pufendorf 3.5.3-7).

This was the mechanism of promising according to the natural law theorists. They attributed to sovereign individuals an ability to bring it about that a free person in a certain respect becomes unfree, subject to another person. This ability of a promisor is exercised when he gives away his control over an action of his in the same manner as he would give away a thing. Once the promisee accepts the promise, the promised action becomes part of his suum. The promisee is now in control, and has the power to decide whether or not the promised action is to be carried out. ${ }^{68}$

The promisor does not alienate the actual power to decide whether or not to perform the action in question. As a matter of fact he can fail to fulfil the promise. What he has lost is the moral freedom or power to decide over the action. This moral power is now with the promisee, who has, accordingly, the facultas moralis to demand fulfilment. If the promisee demands that the promise be fulfilled, the promisor comes under an obligation. Inwardly he is no longer free to decide otherwise. Thus Pufendorf says that the power that has been acquired is that the promisee can prescribe for the promisor what is to be done, suffered or avoided; and such a prescription has obligatory effect (3.5.4; cf 1.6.5). ${ }^{69}$

\section{Promissio dandi}

68 cf Grotius 2.17.2.1. After mentioning the naturally given components of the suum, he continues: Dominio et pactis quomodo suum quid cuique sit, superior tractatio docuit (2.6.1) tum quoad res, tum quoad ius in actiones alienas. Pufendorf 1.7.11: Quod ex iure perfecto mihi debetur, si aliquo modo iam meum esse intelligitur, sic ut quamdui idem non fuerit exhibitum, aliquid mei abesse iudicetur ...

69 Cf Hägerström (n. 48) 54ff, 60ff. 
A promise to transfer at a future time the right of ownership is not described as a transfer of a part of one's freedom. The natural law theorists prefer to say that such a promise is an intial stage of a transfer of the right of ownership itself. ${ }^{70}$ This distinction between a promissio faciendi and a promissio dandi strikes us as rather peculiar. A future transfer of a right of property is also an action. It has been said that the distinction is 'illogical and likely to cause confusion' ${ }^{71}$

The objection, plausible as it may seem, is hardly acceptable. As noted above, the natural law theorists regarded the right of ownership and the right to one's actions equally as parts of the suum. But in the right of ownership was implicit the right to transfer it. The object of the transfer of a right in a promissio dandi was the right to transfer the right of ownership. So a promissio faciendi and a promissio dandi concerned different kinds of rights. In the case of a promissio dandi, the promisor lost the moral freedom to decide over the future transfer of the right of ownership. But this was only a consequence of the fact that he had alienated the right to transfer implicit in the right of ownership. That right had come to belong to the promisee. Therefore the promisee could command the promisor to complete the transfer. ${ }^{72}$

\section{The non-fulfilment of promises}

Through a promise of either kind, that which was promised became part of the suum of the promisee. This had a significant consequence. The non-fulfilment of a promise implied an alienatio alieni. It involved depriving the promisee of something that belonged to him. Non-fulfilment was regarded as an iniuria. ${ }^{73}$

Given this outlook, the precept that promises should be kept is no longer of independent significance. It adds nothing to the general precept not to harm others. The law of nature is reduced to this single principal precept. ${ }^{74}$

\footnotetext{
$70 \quad$ Grotius 2.11.4.1: via ad alienationem rei; similarly Pufendorf 3.5.7.

$71 \quad$ Hägerström (n. 48) 73.

72 A promissio dandi transferred a right that was implied in the right of ownership. The promise could not be valid unless the promisor had the right of ownership. If this was not the case, the promise should be understood to be based on the condition that the promisor acquired the right of ownership to the thing he promised to give. Cf Grotius 2.11.8.2; Pufendorf 3.8.4, where various questions relating to this are discussed.

73 This is clearly stated by Pufendorf, eg 3.1.3 and 1.7.7. The same idea underlies Grotius's statements; see eg 2.1.2.

74 The fundamental importance of theory of the suum has received little attention in the literature. The first modern scholar to have given it more than casual attention is to the best of my knowledge Hägerström. His most instructive work, on rights, duties and the binding force of contracts etc, suffers,
} 
The consequences of committing a wrong

The sphere of the suum was, as Pufendorf puts it (3.1.1), sacrosanct. So the individual had, as it were, ideal protection. ${ }^{75}$

To invade the sphere of another was an act of disobedience against the divine precept not to harm others. The consequence was obviously divine punishment. These punishments were not discussed in natural law theory. It only dealt with the consequences of wrongs among human beings.

In this respect the natural law contained rules concerning compensation and restitution of foreign property. But an iniuria had another consequence. The suum could be defended by resort to force. The law of nature said nothing about that. The important theory of the lawfulness of force is developed independently of any natural law.

In the state of nature, says Grotius, everyone has a right to assert his suum by force. This changed when societies were formed. People renounced in principle the right to use force themselves. It was left to the courts to provide protection for the suum. Still, the original order remained if there was no court that could intervene (eg in cases of assault, and in areas where there was no potestas civilis).

Nations or sovereigns were subject to no earthly power, and they had never renounced the original right of self-defence. In relation to each other they lived in a state of nature. It was therefore for them to decide according to their own judgement to assert their rights by force. This was done by a public war (bellum publicum), which corresponded to the private exercise of force (bellum privatum) in the state of nature.

however, from a failure to take the suum catalogue into account. He describes Grotius's view of the individual's realm as follows (p 50): 'The natural realm of everyone is determined by the conditions for human community or the maintenance of external peace and therefore by the ius naturae [the law of nature].' But this is not what Grotius is saying. He indicates in concrete terms the ingredients of the suum of a human being. In a passage (Grotius 1.1.3.1) referred to by Hägerström, Grotius quotes Cicero’s statement that human society would go under unless the prohibition against alienatio alieni was observed. But this presupposes that there is a realm of the suum. In another place (p 50), a passage which is difficult to understand, Hägerström seems to suggest that the concept of suum in relation to habere or agere is vacuous. This may be so. But what matters is not the definition, but the catalogue that gives content to the theory of suum. On the concept of suum, see Reinhart Brandt, Eigentumstheorien von Grotius bis Kant, Stuttgart-Bad Canstatt: Frommann-Holzboog, 1974) 9ff..

75 Reinhart Brandt aptly describes the suum as 'taboo', op.cit. p. 11. 
Justifying the use of force

This theory of the lawfulness of the use of force faced a certain difficulty. If the attacked party used force against an attacking party he would obviously trespass on the attacker's suum. Apparently he would have done an iniuria to the attacker.

This problem is discussed at length by Pufendorf (2.5.1). He mentions that there are people who have scruples against harming or killing an attacker, who is, after all, a human being like ourselves. It had been said that the loss suffered by mankind if the attacker perishes is similar to the loss if we perish; and using force in one's own defence could lead to greater disturbances among the people than choosing flight or allowing oneself to be killed.

Pufendorf dismisses this pacifist view. As is evident from his biography, he was not one to shun conflict. He supported with great conviction the struggle for law and order.

Reason recommends, and the prevailing opinion of the learned and the common people approves, that one uses force for the purposes of defence if there are no other means. Human beings were created to live together peacefully; and the purpose of all natural laws which concern relations to others is to promote peace. Nevertheless nature tolerates (natura indulget) a recourse to force if other means of protection are unavailable.

The laws of nature are equally binding on all. By nature, nobody has a privilege to disobey these laws and harm another human being, and at the same time the other human beings also remain obliged to preserve peace. If someone directs an attack against me with the aim of destroying me, it would be the grossest arrogance on his part if he were to demand that I should continue to consider him sacred (sacrosanctum habeam), i.e. that I should sacrifice my welfare and let his malice hold sway with impunity. On the contrary: I ought to have concern for my own safety, and the attacker has only himself to thank for what he forces me to inflict on him. Everything that we receive from nature or acquire through our industry would be of no use if we were not allowed to use force in defence of that which is ours.

The principle of reciprocity

There was, then, a principle of reciprocity in the state of nature according to Pufendorf. The sacredness of the person was always on condition that he did not commit an iniuria against another. To do that would lead to a loss of the offender's own sacredness. Therefore the injured party would not commit a wrong in counterattacking.

Grotius presupposes the same principle of reciprocity. Without it, the whole theory of the suum would be quite pointless. What would the suum mean, if the person whose suum was injured had no preferential position in relation to the attacker? The privileged 
position emerged because the attacker had forfeited his sacredness. For there was, of course, no superior power which could intervene to protect the injured party. The person who had suffered injury had to react himself. But such a reaction could take place without iniuria only if the ideal barrier surrounding the opponent had fallen over.

Pufendorf's argument related to attacks on one's life. But the principle of reciprocity was extended to all cases of iniuria. Nothing except iniuria can justify a war, says Grotius (2.1.1.4). By this he means also that every iniuria presents a iusta causa belli and accordingly makes the war just. No distinction is made between serious wrongs and slight ones. Therefore Grotius could say that there are as many grounds for a just war as there are just claims before a civil court. ${ }^{76}$

The extent of the use of force

Another question was how far one could go when reacting with force in response to an iniuria, and whether in that respect a distinction should be made between more and less serious attacks. These problems were discussed in considerable detail.

Grotius begins with the case of a life-endangering attack (2.1.3). If the danger could not be otherwise deflected there could be no doubt that it was permissible to kill the attacker. This would be the case also if he for some reason, eg insanity, was not culpable. According to the pure Natural Law (leaving the Gospel aside) it was even permissible to kill those who prevented the attacked person from defending himself or from escaping (2.1.4.1), provided, of course, that no other means were available. Moreover, pudicitia was placed at the same level as life (2.1.7). Pufendorf (2.5.11) agreed.

\footnotetext{
$76 \quad$ Grotius 2.1.2.1: Plane quot actionum forensium sunt fontes, totidem sunt belli: nam ubi iudicia deficiant, incipit bellum. Not only actual iniuria, but also a threat of iniuria could be a ground for a lawsuit, and accordingly a ground for a just war. In this way some preventive wars could be justified. (This was so in Roman Law: Grotius mentions the interdicts.) This is why Grotius in the first place discusses iniuria nondum facta as a ground for a just war (2.1.2.3: Prima igitur causa iusti belli est iniuria nondum facta, quae petit aut corpus, aut rem). Dunning's opinion (A History of Political Theories II, 1928, p 176) that Grotius, in contrast to Gentili, condemned preventive war, is due to a misunderstanding. What Grotius's objection against Gentili amounts to is only that the mere fact that the strength of another prince or state grows so as to surpass ours is not a sufficient ground for a just war: we also have to be certain, as far as this is possible in moral matters, that the other side is intent on harming us (2.22.5; cf 2.1.17 and 2.1.5.1). The difference of opinion only concerned the strength of one's suspicion concerning the aggressive intent of the other side. Cf Barbeyrac’s note to 2.1.17 in his translation.
} 
If the evil that threatened was less serious, the question arose as to whether one had to limit oneself to a proportionate use of force. Grotius denied this. According to the pure Natural Law there were no such limitations.

As an example Grotius takes the case that one is in imminent danger of receiving a slap in the face. If this could not be otherwise prevented, one would according to the Law of Nature be entitled to kill the attacker (2.1.10.1). Death and a slap in the face are not comparable, but anyone who sees fit to inflict an iniuria on me thereby gives me an unlimited right against him (i.e. to use force). The attacker has forfeited his ideal protection, so that the reaction of the attacked party is not an iniuria. ${ }^{77}$ Love of one's neighbour (caritas) does not compel us to spare one who attacks us. Only the law of the Gospel prohibits us from reacting against such an attack with the use of force.

The same principle applied to the defence of things belonging to us. If it was necessary, the Law of Nature gave permission to kill a robber. If he had seized an object, it was permissible to kill him as he was running away if the object could not otherwise be regained (2.1.11). Grotius makes an exception, however, if the object is of very slight value.

Pufendorf is largely in agreement with Grotius in these matters. He states more than once that an attacker gives us an unlimited right against him. For the most part he uses the word licentia rather than ius. ${ }^{78}$

He, too, rejects the view that justice requires equivalence between attack and reaction. No one has a right to attack: whether the attack is moderate or extreme makes no difference. The principle of equivalence applies only to the imposition of punishments, but this takes place only in human society [and not in the state of nature].

The 'celebrated question' (celebris illa quaestio) of the slap in the face is discussed at some length, and Pufendorf is of the same opinion as Grotius. In the state of nature nobody can be expected to patiently suffer even a fairly minor iniuria. ${ }^{79}$ He explains,

77 The victim commits no iniuria in using force against the attacker, but to say that the attacker has given the victim a right to do so is inaccurate.

78 Pufendorf 2.5.3; also 2.5.10, 2.5.12, 8.6.2, 8.6.7 Licentia, mere permission, is the right word. It is not a right properly so called, since the victim cannot by making a claim create an obligation for the other party. All he can do is use force without thereby committing an iniuria. As Grotius insists, the possibility to act with impunity is not a right properly so called: agendi impunitas improprie ius dicitur (2.5.28).

$79 \quad$ As for less grave insults, Pufendorf (2.5.12) gives the example of King David (sanctissimus Rex) who went to war against the Ammonites because they had insulted his envoys by cutting off half of their hair and clothes (2 Sam 10). [A slap in the face was not trifling. It was the most serious kind of attack on one's honour (equal in seriousness to giving a man the lie). Hobbes observed that 'most men prefer to lose their lives (not to mention their peace) rather than suffer insult' (De cive 3.12). When Pufendorf drafted his major work in the late 1660s, he called the question celebris no doubt because of the widespread attention it 
with great conviction, the importance of the principle that in the state of nature the licence to defend oneself has no definite limit. Pufendorf mentions the case when one's neighbour continuously causes harms [the text has Nachteile (disadvantages), but the supporting quotation from Pufendorf has iniuriae] to oneself, albeit minor ones. It must be permissible to kill him if the nuisance cannot be stopped in any other way (2.5.3).

The question of how far the attacked may go when using force was discussed mainly with reference to situations of immediate danger and recovery of property. But there were, of course, other cases which would call for a reaction involving the use of force on the part of the attacked individual. The non-fulfilment of a contractual debt was an iniuria, and the creditor had the right to compel fulfilment (Grotius 2.1.2.2; Pufendorf 1.7 .7 and 8.6.2-3). Similarly, the right to damages was enforceable. Further, Pufendorf mentions the obtaining of security for the future (8.6.3). Also in these cases the extent of the use of force had no definite limit. In the state of nature, the reaction was in the form of a bellum privatum. And in a war, everything that is necessary in order to achieve one's purpose was permitted. It was, however, commendable to show moderation whenever possible. ${ }^{80}$

\section{The origin of the right of self-defence}

Grotius makes an interesting observation concerning the right of self-defence. According to him this right does not arise from the unlawfulness or sin of the attacker. It springs immediately from nature and what it commends and permits. From the actual impulse to self-defence there emerges a right to self-defence. Everyone is by nature, Grotius says elsewhere, the defender of his right: this is why we were given hands. Nature has given us not only the inclination but also the capacity to defend ourselves. This confirms our right of self-defence.

had attracted after Blaise Pascal's famous attack in the seventh of his Provincial Letters in 1656 on the many (mainly Jesuit) confessors and spiritual advisers who were alleged to disregard, contrary to their vocation, the Law of the Gospel, and to accept that even a lethal defence of one's honour in response to a slap would be perfectly legitimate.]

80 Grotius 3.1.2.1. Pufendorf writes of an attacker (8.6.7): Me quantum in se absolvit a praestandis officiis pacis; eoque dum hostem sese meum profitetur, licentiam concedit vim contra ipsum exserendi in infinitum, aut quantum mihi videatur. Praesertim cum finis belli, sive offensivi sive defensivi, citra licentiam hanc, si necessum foret, vim adversus hostem intra certum modum, et citra ultima sistere, obtineri nequeat. Grotius mentions punishment (punitio) among the war aims (2.1.2.2). In such a case the evil inflicted on the enemy should not exceed that caused by the iniuria. Pufendorf, on the contrary, held that in the state of nature there is no punishment, since the concept of punishment implies that it must be inflicted by a superior. On this disputed question, see Barbeyrac’s translation of Pufendorf $(8.3 .4$, fn 3). 
There is a similar argument in Pufendorf. If someone has the intention to harm me, he says, my interest in my own safety gives me the right to protect myself, even if this should mean that damage is done to the other party. Further, nature has given us hands which have great freedom of movement, together with bodily strength, so we do not have to suffer injuries without retribution. Nature has given us readiness and capacity to defend ourselves, and with this she has also given us the right.

These statements clearly reveal the psychological background to the theory of the consequences of wrongdoing. The human inclination to react against violations is not confined to the most serious ones. Everything that feels like a violation can provoke acts of retribution. When defending oneself against an attack it is not part of human nature to endeavour anxiously to ensure proportionality in repelling a hostile attack: the lust for revenge is not limited to inflicting on the enemy an equivalent evil. We can therefore easily understand that the natural law theorists, when they considered the naturally given consequences of wrongdoing, came to the result that by committing an iniuria, the attacker forfeited his own sacrosanct status, so that, in principle, the reaction had no definite limit.

\section{Summary and conclusion}

The alleged law of nature was a law in the sense in which we commonly understand the word 'law': it consisted of commands and prohibitions issued by a superior power. But it was presupposed that there already existed a certain order. This natural order was not a law in the sense just mentioned. It was an order based on the fact that human beings have certain qualities which determine their relations to each other, independently of any legislation. These qualities determine the initial natural order. The exercise of the human faculty of will could, however, bring about certain changes in this order.

Fundamental to this outlook was the idea that human beings, despite all physical and mental differences, were free and equal. It was of course possible that one individual could in fact be coerced by another. The freedom belonged to the realm of morality. It implied that nobody had a moral power over anyone else: nobody could make a claim against another with the effect that the other came under an obligation to act in a certain way. On the other hand every individual was ideally protected against actual coercion imposed by someone else. The protection consisted in the fact that the human person was sacrosanct. This is why every attack on the person was a wrong; and the consequence of committing a wrong was that the attacker forfeited his own sacrosanct character.

In this way, the natural law theorists arrived at their concepts of right and wrong, iustum and iniustum. Iustum is defined as that which is not iniustum, and iniustum consists in attacking another's personality.

It was, however, necessary to indicate more specifically the circumstances in which something was to count as an attack on the person. The theory of the suum fulfilled this 
function. This was a theory of what it is that belongs to the human person. By nature, it was not only life and body, but also liberty, good reputation, honour (including pudicitia), and one's own actions. Consequently, a wrong was committed not only if someone killed or caused bodily injury to a person, but also when his freedom etc was attacked.

The individual also had a power over himself, a potestas in se, i.e. a power over his personality and that which belonged to it. Therefore he could renounce part of his suum. But the realm of the suum could also be extended. Either way, the will of the individual was the efficient power. Every human being capable of exercising the faculty of reason had a moral capacity to have things as his own and to undertake acts with legal effect.

By means of a volition together with touching (or other physical contact) it was possible for an object which did not belong to anybody to be made one's own. An object could be transferred from the owner to someone else: the transfer was completed by a declaration of will on the part of the recipient. This meant that the object became included in his suum. It was also possible to renounce a power over a particular action, in order to let someone else have that power. When the other party accepted, the power over the act became incorporated in his suum, and he now had a moral power over the promisor; by making a claim, he created an obligation for the promisor to perform as promised.

In this way there existed a system of law (Rechtsordnung) for human beings, independently of any divine or human legislation. Within this order it is determined what belongs to an individual, wherein the lawfulness and unlawfulness of human actions consists, what were the consequences of wrongdoing, and how human beings could, by means of occupation and contract, extend or reduce their lawful realms.

This was not a matter of commands and prohibitions issued by a legislator, but of naturally given conditions, capacities and volitions. A legal order in this sense is something entirely different from a legal order understood as a system of imperatives from a superior power.

The following thought-experiment might be considered. Remove natural laws (Naturgesetze) from the theories of natural law (Naturrecht) here under discussion. What would this mean? Very little. The accounts of the suum, the modes of acquisition, the declarations of will, and iniuria and its consequences, would all remain intact. 